\title{
KARAKTERISTIK EKOSISTEM RUMEN SAPI YANG DIBERI PAKAN SILASE BERBASIS JERAMI JAGUNG
}

\author{
(Rumen Ecosystem Characteristics of Bali Cattle which were given Complete Silage Feed \\ from the basic ingredients of Corn Straw)
}

\author{
Agus Suprayogi ${ }^{1)}$, Nibras Karnain Laya ${ }^{2}$, Muhammad Mukhtar*2) \\ 1SMK Negeri 1 Mootilango, Kabupaten Boalemo, Provinsi Gorontalo \\ 2Jurusan Peternakan Fakultas Pertanian, Universitas Negeri Gorontalo
}

*Coresponding Author: Email: muhammadmukhtar@ung.ac.id

\begin{abstract}
ABSTRAC
The purpose of this study was to determine the characteristics of the rumen ecosystem of Bali cattle which were given Complete Silage Feed with the main ingredient being corn straw. This study was used twelve Balinese cattle which are grouped based on body weight. Bali cattle body weight groups are K1: $160 \mathrm{Kg}-170 \mathrm{Kg}$; K2: $171 \mathrm{Kg}-187 \mathrm{Kg}$; and K3: $204 \mathrm{Kg}-220 \mathrm{Kg}$. This study used a randomized block design (RBD) with four treatments and three heavy groups. Feed care: R0 (85\% Straw corn $+15 \%$ concentrate as a control); R1 (70\% Corn straw + 5\% Gamal leaves + 25\% concentrate); R2 (65\% Corn straw + 10\% Gamal leaves + 25\% concentrate); and R3 (60\% corn straw + 15\% Gamal leaves + 25\% concentrate). Data were analyzed using analysis of variance, through the Exel Program. significant test using LSD. The parameters observed were $\mathrm{pH}, \mathrm{NH} 3$ (ammonia), and VFA (fatty acids). Based on the results of the study showed the $\mathrm{pH}$ value of the rumen fluid was normal (6.80-6.90), the concentration of Ammonia produced: 13.67-31.64. Total VFA production is 70-90 mM, this VFA increases in line with an increase in Gamal leaves by $15 \%$. Feeding Complete Silage from corn straw to Bali cattle does not affect the $\mathrm{pH}$, $\mathrm{NH} 3$, and VFA values in the rumen.
\end{abstract}

Keywords: Rumen, Bali Cattle, Silage, Corn Straw.

ABSTRAK

Tujuan dari penelitian ini adalah untuk mengetahui karakteristik ekosistem rumen sapi Bali yang diberi pakan silase komplit berbasis jerami jagung. Penelitian ini menggunakan Rancangan Acak Kelompok (RAK) dengan empat perlakuan dan tiga kelompok berat badan. Perlakuan terdiri dari R0 (85\% Jerami jagung + 15\% konsentrat sebagai kontrol); R1 (70\% Jerami jagung + 5\% daun Gamal + 25\% konsentrat); R2 (65\% Jerami jagung + 10\% daun Gamal + 25\% konsentrat); dan R3 (60\% Jerami jagung + 15\% daun Gamal + 25\% konsentrat). Kelompok berat badan adalah K1 (160 Kg - $170 \mathrm{Kg}) ; \mathrm{K} 2(171 \mathrm{Kg}-187 \mathrm{Kg})$; dan K3 (204 Kg - 220 Kg). Jumlah sapi Bali 12 ekor (jantan). Data dianalisis secara bervariasi dan selanjutnya diuji menggunakan uji LSD. Parameter dalam penelitian ini adalah $\mathrm{pH}, \mathrm{NH} 3$ (amonia) dan VFA (asam lemak terbang). $\mathrm{pH}$ cairan rumen dalam kondisi normal adalah 6,80-6,90., Konsentrasi amonia yang dihasilkan: 13,67-31,64, Produksi VFA total pada penelitian ini berkisar antara 70 - 90 mM, VFA ini meningkat sejalan dengan peningkatan daun gamal sampai $15 \%$,. Hasil penelitian menunjukkan bahwa pemberian pakan Silage berbasis jerami jagung tidak mempengaruhi nilai $\mathrm{pH}$, NH3 dan VFA.

Kata Kunci : Jerami Jagung, Rumen, Sapi Bali, Silase 


\section{PENDAHULUAN}

Perubahan fungsi lahan sebagai pemukiman dan industri, periode musim kemarau dan musim penghujan, dan menajemen pengelolaan pakan yang tidak tepat, hal ini merupakan salah satu factor yang menghambat pengembangan ternak rumunansia terutama dari sisi ketersediaan pakan yang berkesinambungan. Pengelolaan hasil sampingan pertanian dapat di jadikan langkah tepat guna mengatasi masalah pakan karena bahan ini sangat melimpah.

Limbah pertanian yang dapat dimanfaatkan adalah jerami jagung, saat persediaan rumput segar berkurang disaat nusim kemarau, namun jerami jagung memiliki daya cerna dan nutrisi yang rendah.

Menurut Lubis

kandungan nutrisi jerani jagung adalah $60 \%$ bahan kering, protein $3,3 \%$, abu $4,4 \%$, serat kasar $20,2 \%$, dan lemak $0,7 \%$, sedangkan jerami jagung difermentasi menghasilkan kandungan ADF dan NDF yang baik di inkubasi 2 minggu, (Usman $\mathrm{N} \mathrm{dkk,}$ 2019).

Menurut Pasue dkk (2019) jerami jagung hasil fermentasi trichoderma viride dengan masa inkubasi yang berbeda selama 2 minggu mampu menurunkan kadar lignin 8,57\%, kadar selulosa $32,48 \%$ dan hemiselullosa 22,59\%.

Penggunaan jerami jagung sebagai bahan dasar pakan silase yang komplit, yang lansung diberikan pada ternak sapi masih sangat sedikit informasinya dan Informasi ini sangat penting guna mengatasi keterbatasan pakan disaat musim kemarau.

Tujuan Penelitian ini untuk mengetahui penggunaan jerami jagung dan daun gamal dalam silase ransum komplit terhadap ekosistim rumen, $\quad \mathrm{pH}, \quad$ VFA (volatile fatty acids), dan $\mathrm{NH}_{3}$ (amoniak)

\section{METODE PENELITIAN}

Tahap pertama dalam penelitian ini adalah pembuatan silase. Pakan perlakuan dicampur merata, dan dibuat dalam bentuk silase, selanjutnya pakan silase yang telah tersedia diberikan pada ternak. Pemberian pakan berdasarkan kebutuhan bahan kering yakni 2,5 Bk.

Tahap kedua adalah melakukan analisis isi rumen dari sapi yang mendapat pakan silase komplit berbasis jerami jagung. meliputi Volatile Fatty Acids (VFA) dan NAmmoniak di analisis pada laboratorium Analisis Kimia dan Nutrisi, Fakultas Peternakan Universitas Hasanudin, Makassar. Ternak yang digunakan adalah Sapi Bali sebanyak 12 ekor yang di kelompokkan berdasarkan bobot badan.

Kelompok I adalah sapi bali dengan bobot tubuh $137-170 \mathrm{~kg}$, kelompok II : 171-190 kg, dan kelompok III: 204-220 kg.

Pelaksanaan penelitian menggunakan Rancangan Acak Kelompok (RAK) terdiri dari 4 
perlakuan dan 3 kelompok, dengan persamaan linier:

$$
\begin{aligned}
& A_{i j}=\mu+\tau_{i}+A_{j}+e_{i j} ; \\
& i=1,2,3, \ldots, t \\
& j=1,2,3, \ldots, b
\end{aligned}
$$

Keterangan :

$$
\begin{array}{ll}
\mathrm{A}_{\mathrm{ij}} & =\text { Nilai Pengamatan perlakuan } \\
\mu & =\text { Rataan umum perlakuan } \\
\tau i & =\text { Pengaruh Perlakuan ke- } \mathrm{i} \\
\mathrm{A}_{\mathrm{j}} & =\text { Pengaruh kelompok ke-j } \\
\mathrm{e}_{\mathrm{ij}} & =\text { Pengaruh galat }
\end{array}
$$

Adapun perlakuan sesuai dengan formulasi sebagai berikut :

$$
\begin{aligned}
& \mathrm{R} 0=\text { Jerami jagung pakan } \\
& 100 \% \text { (kontrol) } \\
& \mathrm{R} 1=\text { Jerami jagung } 70 \%+\text { daun gamal } \\
& 5 \%+\text { konsentrat } 25 \% \\
& \mathrm{R} 2=\text { Jerami jagung } 65 \%+\text { daun gamal } \\
& 10 \%+\text { konsentrat } 25 \% \\
& \mathrm{R} 3=\text { Jerami jagung } 60 \%+\text { daun gamal } \\
& 15 \%+\text { konsentrat } 25 \% \\
& \text { Variabel yang damati dalam } \\
& \text { penelitian ini adalah } \mathrm{pH} \text { cairan rumen, }
\end{aligned}
$$

Volatile Fatty Acids (VFA) dalam cairan rumen, dan Kandungan $\mathrm{NH}_{3}$ (Amoniak) dalam cairan rumen.

Perhitungan VFA

$$
\mathrm{VFA}=\frac{(a-b) \times N \text { HCL } x 1000 / m M}{\text { Volume sampel }}
$$

Ket :

VFA = total Asam lemak terbang $/ \mathrm{mmol} / 1$

a $\quad=$ Titrasi blangko

$\mathrm{b} \quad=$ Titrasi sampel

$\mathrm{N} \quad=$ larutan $\mathrm{HCl}$

Perhitungan NH3

$\mathrm{N}-\mathrm{NH} 3(\mathrm{mg} / \mathrm{ml})=(\mathrm{ml}$ titer $\mathrm{HCl} \times \mathrm{N} \mathrm{HCl}) \times$ BM NH3 x 100 mg ml-1.

\section{HASIL DAN PEMBAHASAN}

Nilai pH, N-Amoniak, dan Volatile Fatty Acids karakteristik ekosistem rumen sapi yang diberi silase berbasis jerami jagung disajikan dalam Tabel 1.

Tabel 3. Rata-rata Nilai pH, NH3(Amoniak), dan VFA(Asam Lemak Terbang)

\begin{tabular}{lcccc}
\hline \multirow{2}{*}{\multicolumn{1}{c}{ Variable }} & \multicolumn{4}{c}{ Perlakuan } \\
\cline { 2 - 5 } & R0 & R1 & R2 & R3 \\
\hline pH Rumen $(\mathrm{mM})$ & $6.80 \pm 0.10$ & $6.87 \pm 0.28$ & $6.90 \pm 0.17$ & $6.90 \pm 0.01$ \\
NH3 Rumen $(\mathrm{mM})$ & $13.67 \pm 3.05$ & $31.67 \pm 4.59$ & $24.67 \pm 9.72$ & $21.67 \pm 9.23$ \\
VFA Rumen $(\mathrm{mM})$ & $73.48 \pm 7.84$ & $94.01 \pm 2.96$ & $73.48 \pm 7.84$ & $68.37 \pm 11.84$ \\
\hline
\end{tabular}

Keterangan: Superskrip berbeda pada baris sama menunjukkan perbedaan yang tidak nyata ( $\mathrm{P}>0.05)$; $\mathrm{R} 0=$ Kontrol, $\mathrm{R} 1=70 \%$ jerami jagung $+5 \%$ daun gamal $+25 \%$ konsentrat, $\mathrm{R} 2=65 \%$ jerami jagung $+10 \%$ daun gamal $+25 \%$ konsentrat, R3 $=60 \%$ jerami jagung $+15 \%$ daun gamal $+25 \%$ konsentrat

\section{pH cairan rumen}

Berdasarkan analisis sidik ragam menunjukan bahwa perlakuan silase komplit berbasis jerami jagung tidak berpengaruh nyata terhadap nilai $\mathrm{pH}(\mathrm{P}>0,05)$. Pemberian pakan silase komplit pada ternak sapi terhadap $\mathrm{pH}$ rumen menunjukkan sama ternak sapi yang diberi pakan jerami jagung $100 \%$ (R0)

Rataan $\mathrm{pH}$ cairan rumen pada penelitian ini dapat dikategorikan 
dalam kondisi normal dimna rata-rata $\mathrm{pH}$ cairan rumen perlakuan pakan adalah R0 (6.80), R1 (6.87), R2 (6.90), dan R3 (6.90). Nilai $\mathrm{pH}$ rumen umumnya dicapai 2-6 jam sesudah makan (Dehority \& Trabasso, 2001), sedangkan nilai $\mathrm{pH}$ setelah 4 jam fermentasi yakni kisaran 6-7. Kondisi ini salah satu indikator adanya degradasi pakan yang baik, karena kondisi $\mathrm{pH}$ tersebut, mikroba pencerna serat kasar hidup secara optimum dalam rumen (Jean-Blain, 1991).

dalam paklementasi daun gamal mengganggu keseimbangan mikroorganisme rumen karena tidak menimbulkan perbedaan nyata pada nilai $\mathrm{pH}$ rumen antar perlakuan. Penggunaan daun gamal sebagai upaya meningkatkan nilai nutrisi pakan masih dapat mempertahankan kondisi $\mathrm{pH}$ media untuk kelangsungan proses fermentasi (Natsir, 2012).

Peningkatan pemakaian gamal sebagai sumber RDP pada ransum yangmenggunakan jerami padi dapat meningkatkan konsumsi dan retensi nitrogen serta meningkatkan populasi bakteri proteolitik (Suryani, dkk, 2015).

Menurut Kusumaningrum, dkk. (2018) Penggunaan silase jerami jagung dalam pakan mengakibatkan penurunan $\mathrm{pH}$ setelah inkubasi, dengan rerata $\mathrm{pH}$ pada silase sinambung jerami jagung berkisar antara 6,89-7,02

\section{NH3 (Amoniak)}

Berdasarkan analisis sidik ragam menunjukan silase komplit berbasis jerami jagung tidak berbeda nyata $(\mathrm{P}>0.05)$ terhadap NH3 (Amoniak) jika dibanding dengan perlakuan R0. Pengaruh pemberian pakan silase komplit pada ternak sapi terhadap pembentukkan ammonia menunjukkan sama dengan perlakuan control (R0). Rata-rata konsentrasi amonia yang dihasilkan dari perlakuan pakan komplit adalah tertinggi R1 diikuti R2, R0 dan terendah R3.

Rendahnya konsentrasi amonia yang dihasilkan pada penelitian ini mencerminkan proses fermentasi yang berjalan lebih baik. (McDonald et al., 2002).

Tinggi rendahnya amonia dalam rumen sangat menentukan efisiensi kerja mikroba rumen dalam sintesa protein mikroba, yang mempengaruhi hasil fermentasi bahan organik pakan berupa asam lemak mudah terbang (Volatile Fatty Acids) sebagai energi utama untuk ternak (Haryanto, 2004).

Silase pakan komplit yang diberikan pada ternak domba berpengaruh nyata terhadap konsentrasi NH3 rumen. Kadar NH3 rumen merupakan sumber nitrogen yang utama untuk sintesis protein mikrobia rumen (Hanun, dkk 2019).

VFA (Asam Lemak Terbang)

Volatile Fatty Acids adalah produk utama dari fermentasi 
mikrobial rumen. Volatile Fatty Acids melaui sistim didalam rumen dimanfaatkan oleh ternak untuk kebutuhan pokok dan pertumbuhan (Nopitasari et al., 2013)

Perlakuan silase berbasis jerami jagung tidak berbeda nyata $(\mathrm{P}>0.05)$ terhadap Volatile Fatty Acids (VFA) atau Asam Lemak Terbang. Pemberian pakan silase komplit pada ternak sapi terhadap pembentukkan Volatile Fatty Acids (VFA) didalam rumen menunjukkan sama ternak sapi yang diberi pakan jerami jagung 100\% (R0), hal ini disebabkan kemampuan mikroba didalam rumen untuk mencerna $100 \%$ jerami jagung sama dengan mikroba yang mencerna silase jerami jagung. Kondisi ini menggambarkan sebagian energi dalam pakan terurai menjadi gas metana dari energi yang ada di dalam pakan. (Haryanto, B. 2018). Pencernaan karbohidrat dalam rumen menghasilkan produk utama berupa Volatile Fatty Acids merupakan sumber kerangka karbon bagi bakteri dan energi bagi ternak ruminansia.

Produksi Volatile Fatty Acids total pada penelitian ini berkisar antara 70 - $90 \mathrm{mM}$, hasil ini masih berada pada kisaran konsentrasi Volatile Fatty Acids yang menunjang kondisi sistem rumen secara optimal.

Menurut Waldron dkk, (2002) Volatile Fatty Acids total berkisar 60120 mM. Pakan komplit yang tidak disuplementasi dengan daun gamal menghasilkan total Volatile Fatty Acids lebih kecil dibandingkan dengan ransum yang disuplementasi daun gamal (R1, R2 dan R3). Hasil produksi Volatile Fatty Acids rendah mnggambarkan leguminosa daun gamal sangat yang baik untuk pakan ternak ruminansia khususnya sapi potong menggantikan sebagian pakan berserat.

Data menunjukan bahwa Volatile Fatty Acids (VFA) dalam rumen meningkat sejalan dengan peningkatan daun gamal sampai $15 \%$ didalam ransum, ini menunjukkan adanya peran daun gamal dalam meningkatkan kualitas fermentasi ransum didalam rumen.

Volatile Fatty Acids yang tinggi pada ransum perlakuan (R3) menggambarkan bakteri rumen bertumbuh dengan baik dibandingkan perlakuan lainnya. Hal ini ditunjang oleh konsentrasi amonia di perlakuan R3 yang lebih rendah dibandingkan dengan perlakuan lainnya.

Volatile Fatty Acids meningkat dan konsentrasi amonia rendah (R3) mencerminkan rendahnya penggunaan amonia untuk sintesis protein dan pertumbuhan oleh bakteri., selanjutnya pakan akan dicerna oleh bakteri guna menghasilkan Volatile Fatty Acids untuk sumber energi yang di gunakan ternak dan karbon digunakan oleh bakteri itu sendiri.

Volatile Fatty Acids merupakan sumber energy utama untuk ternak ruminansia (Preston dan Leng, 1987; Arora, 1989). Menurut Russel, dkk (2009) mengungkapkan 
pemberian ransum yang bersifat lebih mudah terfermentasi atau fermentable akan mengakibatkan Volatile Fatty Acids yang di produksi akan diserap dalam waktu yang lebih cepat.

Menurut Fahey dan Berger, (1988) Produksi Volatile Fatty Acids didalam rumen berhubungan erat dengan dengan kemampuan bakteri, dan aktivitas bakteri ditentukan oleh nutrien yang tersedia, disamping kondisi rumen selama fermentasi dan waktu setelah makan, sedangakan Chuzaemi, (1994)., Fathul, dkk, (2009) menyatakan asam butirat, asetat, untuk oksidasi ketogenik, sedangkan asam propionat untuk glukoneogenesis atau glukogenik.

Menurut Kusumaningrum, dkk. (2018) Penggunaan jerami jagung dalam fermentasi in vitro, maupun waktu inkubasi tidak mempengaruhi terhadap nilai $\mathrm{pH}$, Volatile Fatty Acids (VFA), NH3, produksi gas total dan produksi biomassa mikroba serta tidak terdapat interaksi dengan waktu inkubasi, namun kisaran $\mathrm{pH}$ adalah 6,89 - 7,05; konsentrasi Volatile Fatty Acids (VFA) sebesar 107-110 mM, Konsentrasi amonia 23,92 - 29,88 $\mathrm{mg} / 100 \mathrm{ml}$, produksi gas total sebesar $27,47-46,31 \mathrm{ml} / 200 \mathrm{mg}$ dan produksi biomassa mikroba sebesar 40,60 - 56,80 $\mathrm{mg} / 20 \mathrm{ml}$ mencukupi kebutuhan ternak ruminansia sehingga baik jerami jagung maupun silase jerami jagung dapat digunakan sebagai pakan ternak karena mampu memenuhi kebutuhan nutrien ternak ruminansia ditinjau dari produksi gas dan fermentasi pakan dalam rumen secara in vitro.

\section{KESIMPULAN}

Silase berbahan dasar Jerami Jagung yang diberikan pada ternak sapi bali tidak memberikan pengaruh nyata $(\mathrm{P}>0.05)$ terhadap nilai $\mathrm{pH}$, konsentrasi NH3 (Amoniak) dan Volatile Fatty Acids (VFA) atau asam lemak terbang dalam rumen

\section{DAFTAR PUSTAKA}

Arora, S. P. 1989. Pencernaan Mikroba pada Ruminansia. Diterjemahkan oleh: Retno Murwani. Gadjah Mada University Press, Yogyakarta.

Fahey, G.C. and L.L. Berger. 1988. Carbohydrate nutrition of ruminants. In: The Ruminant Animal Digestive Physiology and Nutrition, Church, D.C (ed). Prentice Hall, New Jersey. Pp: 269295.

Fathul, F. dan Wajizah, S. 2009. Penambahan mikromineral Mn dan $\mathrm{Cu}$ dalam ransum terhadap aktifitas biofermentasi rumen domba secara in vitro. JITV,15 (1) :915.

Haryanto, B. Supriyati, dan S.N. Jarmani. 2004. Pemanfaatan probiotik dalam bioproses untuk meningkatkan nilai nutrisi jerami padi untuk pakan domba : Prosiding Seminar Nasional 
Teknologi Peternakan dan Veteriner. Bogor, 4-5 Agustus 2004. Puslitbang Peternakan, Bogor. hlm. 298-304.

Haryanto, B. (2018). Review of ruminant nutrition research.

Hanun, L., Muktiani, A., dan Nuswantara, L. K. (2019). Pengaruh Penggunaan Silase Pakan Komplit Berbahan Eceng Gondok Terhadap Nilai Kecernaan Protein Pada Ternak Domba. Mediagro, 15(01).

Kusumaningrum, C. E., Sugoro, I., \& Aditiawati, P. (2018). Pengaruh Silase Sinambung Jerami Jagung Terhadap Fermentasi Dalam Cairan Rumen Secara In Vitro. Jurnal Ilmu Ternak Universitas Padjadjaran, 18(1), 26-33.

Leng, R. A. 1987. Tree Foliage in Ruminant Nutrition.Food and Agriculture Organization of the United Nations, Roma

Lubis, D. A. 1992. Ilmu Makanan Ternak. PT Pembangunan, Jakarta.

McDonald, P., R. Edwards, and J. Greenhalgh. 2002. Animal Nutrition. 6thEdition. New York.

Natsir, A. 2012. Fiber utilization by ruminants. Publish Masagena press. Makassar
Pasue, I., Saleh E.J, Bahri S. 2019 Analisis Lignin, Selulosa Dan Hemi Selulosa Jerami Jagung Hasil Di Fermentasi Trichoderma Viride Dengan Masa Inkubasi Yang Berbeda, Jambura Journal of Animal Science vol 1, No 2, $2019 . \quad$ DOI: https://doi.org/10.35900/jjas.v1i 2.2607

http:/ / ejurnal.ung.ac.id/index.p hp/jjas/article/view/2607

Russell, J.B., Muck, R.E., and Weimer, P.J. 2009. Quantitative analysis of cellulose degradation and growth of cellulolytic bacteria in the rumen. FEMS Microbiol Ecol 67:183-197.

Suryani, N. N., Mahardika, I. G., Putra, S., dan Sujaya, N. (2015). Pemberian gamal tambahan dalam ransum meningkatkan neraca nitrogen dan populasi mikrob proteolitik rumen sapi bali. Jurnal Veteriner Maret, 16(1), 117-123.

Usman, N., Saleh E.J., Nusi M. 2019 Kandungan Acid Detergent Fiber Dan Neutral detergent Fiber Jerami Jagung fermentasi Dengan Mengunakan Jamur Trichoderma Viride Dengan Lama Inkubasi Berbeda, Jambura Journal of Animal Science, Vol 1, No 2, 2019. DOI:

https:// doi.org/10.35900/jjas.v1i

2.2606 
http:/ / ejurnal.ung.ac.id/index.p $\mathrm{hp} /$ jjas/article/view/2606

Waldron, MR. et al., 2002. Volatile fatty acids metabolism by epithelial cells isolated from different areas of the ewe rumen. J of Anim Sci. 80: $270-278$.
Nopitasari, S., Widiyastuti, T. dan Sutardi, T.R. (2013). Pengujian Kecernaan Bungkil Biji Jarak Hasil Fermentasi ditinjau dari Produksi VFA dan NH3 secara In Vitro. Jurnal Ilmiah Peternakan, $1(2), 446-454$. 